\title{
MTR wt Allele
}

National Cancer Institute

\section{Source}

National Cancer Institute. MTR wt Allele. NCI Thesaurus. Code C104948.

Human MTR wild-type allele is located in the vicinity of $1 \mathrm{q} 43$ and is approximately $109 \mathrm{~kb}$ in length. This allele, which encodes methionine synthase protein, is involved in the synthesis of methionine. Mutation of the gene is associated with both methylcobalamin deficiency type $\mathrm{G}$ and susceptibility to folate-sensitive neural tube defects. 